\title{
Challenges Encountered by Junior High School Students in Learning Science: Basis for Action Plan
}

\author{
John Rae N. Sadera, Rianna Yvette S. Torres, Danilo V. Rogayan, Jr.* \\ College of Teacher Education, President Ramon Magsaysay State University - San Marcelino 2207, Philippines
}

Received March 5, 2020; Revised November 3, 2020; Accepted November 11, 2020

\section{Cite This Paper in the following Citation Styles}

(a): [1] John Rae N. Sadera, Rianna Yvette S. Torres, Danilo V. Rogayan, Jr., "Challenges Encountered by Junior High School Students in Learning Science: Basis for Action Plan," Universal Journal of Educational Research, Vol. 8, No. 12A, pp. 7405 - 7414, 2020. DOI: 10.13189/ujer.2020.082524.

(b): John Rae N. Sadera, Rianna Yvette S. Torres, Danilo V. Rogayan, Jr. (2020). Challenges Encountered by Junior High School Students in Learning Science: Basis for Action Plan. Universal Journal of Educational Research, 8(12A), 7405 - 7414. DOI: 10.13189/ujer.2020.082524.

Copyright $\odot 2020$ by authors, all rights reserved. Authors agree that this article remains permanently open access under the terms of the Creative Commons Attribution License 4.0 International License

\begin{abstract}
Science education is an essential element in thriving and surviving in a volatile, uncertain, complex, ambiguous, disruptive, and diverse $\left(\mathrm{VUCAD}^{2}\right)$ world. This cross-sectional research determines the challenges of junior high school students in learning science. A total of 123 junior high school students from four government-owned high schools in Zambales, Philippines, served as respondents of the study. Descriptive and inferential statistics were employed in analyzing the data. The developed Challenges in Learning Science Questionnaire (CLSQ) was used as the primary data gathering tool $(\alpha=0.95)$. Results revealed that junior high school students generally encounter not much challenges across all domains in learning science $(\mathrm{M}=2.06)$. However, based on the qualitative data, students encounter some issues and problems in learning the subject in terms of student motivation, student cognitive ability, teacher characteristics, subject matter content, medium of instruction, learning environment, instructional resources, curriculum and parental support. The t-test comparison revealed that male students encounter more challenges in terms of instructional resources and parental support compared to their female counterparts. The proposed action plan is crafted to minimize further the challenges encountered by the students in learning science. The teachers may consider varied and innovative pedagogical practices to explain better complex and complicated topics for better Science learning in a VUCAD ${ }^{2}$ world.
\end{abstract}

Keywords Challenges in Learning Science, Science Education, Science Learning, VUCAD ${ }^{2}$ World

\section{Introduction}

Science education has been part and parcel of the curricular programs of basic up to higher education. The science curriculum distinguishes the role of science and technology in daily human activities [1]. Sunga and Hermosisima [2] claimed that science education is an important key to succeed in today's global knowledge environment profoundly shaped by science and technology. Moreover, science education is vital in navigating the volatile, uncertain, complex, ambiguous, disruptive, and diverse $\left(\mathrm{VUCAD}^{2}\right)$ world, which is considered a new normal in education. Morales [3] reiterated that education in the modern world faces compounded uncertainties due to globalization and the extensive and contemporary use of technologies. Manalansan et al. [4] stressed that it is imperative to develop the passion and love for learning in a VUCAD ${ }^{2}$ world among students.

However, many countries around the world face serious challenges in science education. According to Kaptan and Timurlenk [5], the main problems include insufficient teacher salary and professional development opportunities, students lack motivation in studying, achievement gaps in science and math, large class size, inadequate school, and intensive curriculum but lacking time allocation for science education.

In the Philippines, science education is likewise ailing. 
Orleans [6] revealed that the existing state of science education in the country, mostly in the basic education level, lags behind other countries in the world. International and local studies have revealed that Filipino students have low retention of concepts and inadequate reasoning and analytical skills [7]. A large section of Grade 6 and fourth-year learners in specified schools cannot apply perceptions to real-life problem-solving scenarios nor create an inquiry to explain a problem [7]; and student performance in Trends in International Mathematics and Science Study [8] and the National Achievement Test is constantly low $[9,10,11]$.

At the helm of the 21st-century society and the onset of the fourth industrial revolution (FIRe), science learning remains to be confronted with numerous challenges. Several studies have confirmed this scenario. Science education faces problems such as scarcity of instructional resources, training of educators, and disapproval of pioneering science teaching [12]. Furthermore, Kaptan and Timurlenk [5] stated that some of the pressing challenges in learning science are an insufficient number of science teachers, lack of motivation among learners and low self-assurance in learning science, huge numbers of students in every class, broken connection with other lessons, inadequate number of laboratory equipment and facilities, insufficient time distribution for science education despite the intensive curriculum. With the inception of Education 4.0, students are likewise expected to be digitally literate to learn science better [13].

Restructuring current science education has re-focused on teaching the learners to be conversant and conclusive about how science influences their lives and uses scientific knowledge to solve difficulties [14]. This is congruent with the Philippine science education under the $\mathrm{K}$ to 12 curriculum which puts science education at the core of emerging scientific literacy among learners that will formulate them to be knowledgeable and participative citizens who can formulate verdicts and concerning applications of scientific knowledge that may have social, health, or environmental impacts [1]. STEM education had contributed vital importance in building the nation's productivity [15].

To respond to the Philippine science education curriculum's core objective to develop scientifically-literate learners, it is essential to revisit and better understand what impedes the students to learn Science better. Hence, this prompted the researchers to find out the challenges of junior high school students in learning Science. This study could inform science educators regarding the students' challenges and how they can respond to these dilemmas towards a quality science education in the Philippines.

\subsection{Learning Science}

When it comes to both industrialized and developing nations science education is mainly important. It helps to promote industrial progress, global economic competition and growth [16].

Science and technology inhabit a vital position in the school curriculum. It is a substantial subject from primary to junior secondary to senior secondary school levels of the educational system [17].

Because of its capability to clarify numerous natural occurrences and the fundamental role it plays in the world's existing development science has remained and would continue to contain great importance. In our century, it is the nation's depth of success, especially in the economic and technological progress and refining the value of life of the persons and society. Throughout the years, science as a school subject gained distinction in the school curriculum and acquired innovations that are observed worldwide [18].

A good science education in the different education levels contributed to enhancing scientific literacy and anticipated to influence learners to study the qualified science courses offered at universities [19].

The goal is to instill and empower each learner with the skills and expertise needed to solve the learner and community's problems. This opposes the traditional school of thought curriculum which is designed only to teach learners how to read and write [20].

According to Kola [21], numerous industrialized nations acquired a lot of knowledge in science and technology because of science education. Science education is significant to any nation's progress; that is why every nation must take it very seriously in all learning institutions because science education deals with sharing of science content and methods to individuals who are not considered habitually to be an affiliate of the scientific community.

Today, science diversely influences things, science is a very broad topic to be discussed. Our niche that we are taking in this particular environment affects our knowledge and perception of science. Educators and learners should be mindful that those spaces where all the scientific events and theories are being discussed are not restricted to the classroom. Science being comprehensive also has different challenges involved in it [22].

Despite how science has a significant impact on everyone, a large section of the human population does not comprehend science or its value, and its probability for economic and social progress. The processes and concepts of science are of boundless position to everybody, not only in their personal lives but also in their local lives, so that they take a knowledgeable part in social decisions, and in their economic lives, where they need to respond absolutely to the changes in the science-related features of their lives. The significance of science to society's future is expected to be considerably more extensive than its impact on human concerns in the past. It is primarily in the advanced world that science and technology contributed to individual fulfillment, welfare 
of communities, and nations' wellbeing [5].

The science course is an important course that prevents the student from falling behind the times not only because it provides information that we can use in all aspects of our lives through its branches of physics, chemistry and biology, but also due to the ever changing and advancing structure of technology content [23].

Science education is a major field of practice, with science being imparted and educated at various educational levels, both and through more informal methods all around the world. In most nations, science is seen as a key factor of schooling. Higher education in science subjects is usually considered a major value for obtaining societal requirements such as ensuring the supply of professionals working in scientific fields and guaranteeing sustainable economic progress [24].

\subsection{Science Education in the Philippines}

According to Ambag [25], our country's state of science education is not considered at strength. Results from the year 2014 shows the passing rate for the national achievement test (NAT) for grade six pupils is only $69.21 \%$. The passing rate for secondary schools appears to be worse, only having a passing rate of only $46.38 \%$ from 2010 statistics. Other international surveys such as Trends in International Mathematics and Science Study (TIMSS) showed that the Philippines has exhibited a consistently abysmal performance.

In the Philippines, most of the students are facing several challenges, examples are family problem, poverty, and large number of students in each classroom, lack of motivation and low self-confidence, difficulty in science and bullying. Each of these problems put a great impact on the students' learning process.

Science education in the country is at its edge. When it comes to science, numerous aspects can be attributed to the country's current dilemma. Some of these are the scarcity of educators in the country, lack of teaching space and absence of science laboratories, the poor quality of students' learner's module, and numerous educators reporting that the books are outdated and flooded with errors. As mentioned earlier, Philippine education's problems harshly limit how most public schools can teach science to their students. Knowing these restrictions in science teaching, it is not a surprise how our fellow Filipinos perceive science [25].

From one of the best in Asia, the country's state when it comes to science education, is now known to be lagging behind other countries specifically in the Southeast Asian region, such as Thailand, Malaysia, and Singapore, in terms of excellence and access to instructional resources [6].

Having the goal to have an internationalized economy, higher educational institutions (HEIs) are mandated to produce professionals. HEIs must ensure the relevance of science education program outcomes in the new industrial era in which machine intelligence and disruptive technologies are transforming the educational setting [26]. There is a requirement to consider the factors linked to the enthusiasm to contribute and compete in a more globalized higher education setting, such as the diverse pointers of quality and efficacy of Philippine higher education [27].

The Department of Education (DepEd) in the Philippines implemented the new K-12 Curriculum, which started in school year 2012-2013 by virtue of Republic Act No. 10533 or the Enhanced Basic Education Law of 2013. The new science curriculum program includes many modernizations in terms of planning competencies, integrating each branch of science in every grade level, mode of instruction, and learning pedagogies [28].

\subsection{Challenges in Learning Science}

Science and technology inhabit a dominant position in the growth and progress of the nation. It helps in developing progress that leads to the advancement and success of a country. Despite the positive feedback of studying science education, it has been observed that learners are fearful of studying the subject [29]. This implies the negative attitude and poor performance of learners in learning science and technology.

In today's $21^{\text {st }}$-century, students are facing multiple problems in the field of science education. Explanations based on science and technology are likely to offer corrective measures to some of these difficulties. Yet, as we recognize today, science and technology are not accessible to a vast human population. Some of society's persistent problems today are linked to the depletion of natural resources, growing poverty, hunger, and illiteracy in many nations worldwide [5].

There were several challenges interrelated to the lack of infrastructure and resources for teaching science. Challenges related to learners' background, the language of instruction, and lack of parental support are also present. Having these challenges, learning is negatively affected which should be immediately addressed [30].

Idiaghe [31] states that accessibility with the resources and academic efficiency among students are strictly connected. The inadequacy of resources could lead to unproductivity among learners. Students in institutions with scarce instruction and learning amenities performed lower, unlike their counterparts in schools with enough facilities.

Researchers worldwide have observed a widespread collection of issues and problems in education faced by students today. According to the study of Tan and Kim [32], the quick advancement in science and technology, newly recognized societal and cultural norms and values, and changes in the climate and environment, as well as the depletion of natural resources all significantly impact the 
lives of children and youths, and hence their ways of learning, viewing the world, experiencing phenomena around them and interacting with others. These changes challenge science educators to rethink the epistemology and pedagogy in science classrooms today as the practice of science education needs to be proactive and relevant to students and prepare them for life in the present and in the future.

Anderman and Sinatra [12] stated that some of the challenges in the field of science education include the unavailability of classroom resources, appropriate textbooks and the preparation and training of science teachers, religious and political opposition to cutting-edge science instruction, the requirement to meet standard and to formulate students for standardized examinations, and the dramatically increasing information using the internet as a source. Given these and other problems, it is tremendously important to understand, recognize, and build upon the abilities of adolescent learners, while at the same time tailoring instruction to address the exclusive challenges faced by this age group.

The significant place occupied these subjects in the school curricula is a role out of Science and Technology in scientific and technological development, as a required condition or requirement in national building. However, the teaching of these relevant subjects is bound by problems; such as the problem of inadequate and substandard learning materials, culture/belief, class size, students' general attitudes, and poor reading habit Science and Technology anxiety [17].

Science education in all levels of schooling is consistently seen as abstract and irrelevant to real-life situation. Students in biology and chemistry are burdened with memorization of truths, and students in physics and mathematics feel that their discipline contents are abstract and cannot relate these materials to the real world. Students in all-purpose fail to see that science is in nature all around them, and the scientific method is widely appropriate in different aspects of their lives [19].

\subsection{Theoretical Framework}

The study is anchored on the Attribution Theory of Harold Kelley and Bernard Weiner. People are interested to assign causes to their actions and behaviors [33]. In social psychology, attribution is the process by which people explain the causes of behavior and events. The process is called attribution theory. The present study identified the challenges in learning science among high school students and to which factors they attribute these challenges.

In learning science, humans increase their understanding of scientific concepts and procedures. Science is the study of phenomena and events around us through systematic observation and experimentation. Science students cultivate their knowledge about the world and enhance their scientific thinking. Through the inquiry process, students will know the nature of science and develop scientific knowledge and science process skills to support them evaluate the effects of scientific and technological development. This will formulate students to participate in public discourse in science-related issues and become lifelong learners in science and technology.

\subsection{Purpose of the Study}

This study aimed to determine the challenges encountered by junior high school students in learning science along with the domains of student motivation; student cognitive ability; teacher characteristic; subject matter content; medium of instruction; learning environment; instructional resources; curriculum; and parental support.

\section{Methodology}

\subsection{Research Design}

The study used a descriptive-survey research design with survey questionnaires as the main instrument in gathering the required data. The present study surveyed the challenges of the students in learning science using quantitative and qualitative approaches.

Descriptive research is a quantitative research method that attempts to gather quantifiable data for statistical analysis of the population sample. It is a popular market research tool that allows gathering and describing the nature of the demographic segment.

\subsection{Respondents and Research Locale}

The study respondents were 123 Grade 9 junior high school students from four state-owned secondary schools in Zambales, Central Luzon, Philippines. Grade 9 students were chosen so they can have another one year for the proposed action plan later. In terms of sex, there are 61 (49.6\%) males and $62(50.4 \%)$ females.

The respondents were chosen through convenience sampling. It is a non-probability sampling where respondents are chosen because they are convenient data sources for the researchers [34].

\subsection{Research Instrument}

The Challenges in Learning Science Questionnaire (CLSQ) developed by the researchers served as the main instrument in gathering the data (Appendix A). It is composed of two parts. The first part consists of the demographic profile of the participants. The profile of the students includes school and sex. The next part is the respondents' problems in learning science, which include 
Student Motivation, Student Cognitive Ability, Teacher Characteristic, Subject Matter Content, Medium of Instruction, Learning Environment, Curriculum and Parental Support. The survey tool is a researcher-made questionnaire. Some concepts were lifted from several studies $[5,8,18]$. The survey questionnaire was subjected to construct and content validity. Three experts were chosen to check the consistency of the items in each variable. A total of 38 students who were not part of the study were asked to answer the survey questionnaire.

The instrument's reliability was established by administering the instrument to the respondents who were nonparticipants of the study. This was done to determine the accuracy of the instrument in measuring the variables related to this research. The computation of the reliability test using Cronbach Alpha was made through SPSS. It was found out that the instrument has an acceptable internal consistency having obtained a Cronbach's Alpha coefficient of 0.955. Ibanez as cited in Rondaris, Ibañez \& Varela [35] contends that an instrument's score is only interpretable when it possesses a substantial internal consistency and when each item in the instrument measures the same construct as the rest of the items. Therefore, internal consistency correlations are essentially measuring of homogeneity, with Cronbach's Alpha, being the most widely used measure. The generally agreed upon lower limit for this type of diagnostic measure to assess the internal consistency of an instrument is 0.70 , although it may decrease to 0.60 in exploratory research.

\subsection{Data Gathering and Analysis}

After the development of the research tools, the researchers secured permission and approval to the school principals for the data collection. The researchers administered the survey questionnaires to 123 students and have given them 20 to 30 minutes to respond. The retrieval of the survey questionnaires took place in the same day.

For data analysis, the computer software SPSS version 22 and MS Excel 2016 were used to process data. The statistical tools which was used in the analysis and interpretation of data and hypotheses testing include descriptive and inferential statistics.

\section{Results and Discussion}

\subsection{Challenges Encountered by Students in Learning Science}

Table 1 shows the challenges encountered by the junior high school students.

Generally, students do not experience much challenges in learning science in all aspects based on the quantitative results of the study. Although not considered as a great challenge, students obtained highest means in the instructional resources $(\mathrm{M}=2.46$; $\mathrm{SD}=0.55)$; medium of instruction $(\mathrm{M}=2.33 ; \mathrm{SD}=0.49)$; curriculum $(\mathrm{M}=2.30$; $\mathrm{SD}=0.50)$; and parental support $(\mathrm{M}=2.30 ; \mathrm{SD}=0.50)$. This implies that the students generally are challenged in terms of the learning resources in science, the use of English in science teaching, the science education curriculum which involves spiral progression and the support coming from guardians and parents for their academic pursuits.

Table 1. Challenges in Learning Science

\begin{tabular}{|c|c|c|c|}
\hline Challenges & $\begin{array}{c}\text { Weighted } \\
\text { Mean }\end{array}$ & SD & $\begin{array}{c}\text { Verbal } \\
\text { Description }\end{array}$ \\
\hline Student Motivation & 2.03 & 0.54 & Not Much \\
\hline Student Cognitive Ability & 2.13 & 0.55 & Not Much \\
\hline Teacher Characteristics & 1.76 & 0.59 & Not Much \\
\hline Subject Matter Content & 2.26 & 0.47 & Not Much \\
\hline Medium of Instruction & 2.33 & 0.49 & Not Much \\
\hline Learning Environment & 2.07 & 0.81 & Not Much \\
\hline Instructional Resources & 2.46 & 0.55 & Not Much \\
\hline Curriculum & 2.30 & 0.50 & Not Much \\
\hline Parental Support & 2.30 & 0.50 & Not Much \\
\hline Average Weighted Mean & 2.06 & 0.65 & Not Much \\
\hline
\end{tabular}

The lowest means were obtained in the following: subject matter content $(\mathrm{M}=2.26 ; \mathrm{SD}=0.47)$; student cognitive ability $(\mathrm{M}=2.13 ; \quad \mathrm{SD}=0.55)$; learning environment $(\mathrm{M}=2.07 ; \mathrm{SD}=0.81)$; student motivation $(\mathrm{M}=2.03 ; \mathrm{SD}=0.54)$; and teacher characteristics $(\mathrm{M}=$ $1.76 ; \mathrm{SD}=0.59$ ). This suggest that these aspects of science learning are not much of a challenge among the students.

The qualitative responses during the interview among select students revealed that students face a myriad of challenges in learning science. Based on the interview, student motivation was one of the challenges of the students in learning science. One respondent from the interview said that lack of interest and knowledge about science is one of his greatest challenges. This implies that motivation in science learning could influence one's desire to attain new knowledge and skills. This is congruent to the study of Kaptan and Timurlenk [5], which stated that one of the leading challenges in learning science nowadays was the lack of motivation and interest of the learners in science. Another study from Schulze and Lemmer [36] states that motivated learners are usually one step higher compared to their peers when it comes to learning. Motivation is the rate in which learners invest their interest, effort and attention in learning.

Another student stated that she has difficulty in formulating conclusions after performing experiments. This implies a problem with the student's cognitive ability that can be regarded as one of the challenges in science learning. It is parallel with Sunga and Hermosisima [2], which stressed that international and local research revealed that Filipino students have low retention of ideas and have limited reasoning and analytical skills. Another participant mentioned that the teacher's voice is not so 
loud that sometimes they cannot hear the lectures and at the same time they also do not understand the lessons that are being taught. This shows that the teacher's good voice modulation is needed so that students can easily understand the topics. Another student stated that the lessons about computation in the chemistry and physics subjects are not well-explained. This suggests that teachers must focus on delivering the lessons well so that the students can easily understand the topics. This is similar with the claims of Darling and Hammond [37] that in producing larger student achievements, teachers must have adequate academic preparation and should be competent in the subject matter content. Likewise, Orleans [6] noted that a vital factor influencing student's performance based on research findings was the teacher's or teaching quality.

Subject matter content was also cited as a challenge in learning science among the students interviewed. They stated that computations related to chemistry and physics subjects are too hard, which shows poor conceptual understanding of the subject matter. This is anchored to the study of Kwok [38] which mentions that students with science subjects are burdened with the rigorous content of the subjects that leads to the poor students' performance in learning science and technology. Furthermore, several respondents shared that the medium of instruction is a challenge for them in learning science. Since Filipino students are non-native English speakers, they face difficulty in understanding the lessons as a result of the frequent use of English as the medium of communication in the class. In the Philippine context, Science is taught in the English language which is considered to be the second language of the Filipino learners. Another respondent stated that the teacher's frequent use of the English language in class, resulting in misunderstanding and failure to comprehend the science lessons. It, therefore, appears that language has an important implication in the better understanding of scientific concepts. The study of Launio [39] states that one distinctive feature of the Philippine educational system is the use of foreign language as a medium of instruction. Complaints are detected that students may hardly perceive straightforward pure English as a medium of instruction in their lessons. This might be one of the explanations for the poor performance of the students.

In terms of the learning environment, one respondent said "not all of my classmates help in accomplishing group activities given by our teacher leading to the unbalanced partition of workloads in class." Another respondent also stated that she cannot understand their discussions because these are sometimes interrupted by the noise of her classmates. Baker and Young [40] revealed that classroom environment is one of the most important factors affecting student learning. The study of Dunlosky [41] explains that the learning environment's conditions are regarded to have a great factor for the students learning. It greatly affects the student's skill and attitude towards learning by either enhancing or diminishing it.

Another respondent stated that "some of the science experiments are not conducted because equipment for science experiments are usually lacking." This implies that there is an inadequacy and insufficiency of resources for science instruction in the Philippines' public education system. This corroborates the study of Anderman and Sinatra [12] that some of the complex issues in the field of science education include the unavailability of appropriate textbooks and classroom resources. Given these and other issues, it is very important to understand, acknowledge, and build upon the abilities of adolescent learners while at the same time tailoring instruction to address the unique challenges faced by this age group.

As shared by one participant, "the division of topics or lessons are confusing compared to the old curriculum, for example, topics about biology are only discussed when you are at the 8th grade, chemistry when you are in the 9th grade unlike now topics about biology, chemistry and physics are mixed." This implies that lessons, even though connected, still appear confusing for some students. The current science education curriculum follows the spiral progression approach wherein topics are taught from simple to complex across grade levels. Most countries implementing the spiral progression approach in their educational system, shared that the said approach does not apply to their learners' needs [42].

\subsection{Difference in the Respondents' Challenges in Learning Science by Sex}

Table 2 presents the independent samples t-test of the challenges encountered by the students when grouped according to sex. 
Table 2. Independent Samples t-test of the Challenges Encountered by Students in Learning Science by Sex

\begin{tabular}{|c|c|c|c|c|c|}
\hline Challenges & Sex & Mean & SD & t-value & p-value \\
\hline \multirow{2}{*}{ Student Motivation } & Male & 2.06 & 0.60 & \multirow{2}{*}{0.674} & \multirow{2}{*}{0.501} \\
\hline & Female & 1.99 & 0.47 & & \\
\hline \multirow{2}{*}{ Cognitive Ability } & Male & 2.14 & 0.60 & \multirow{2}{*}{0.313} & \multirow{2}{*}{0.755} \\
\hline & Female & 2.11 & 0.51 & & \\
\hline \multirow{2}{*}{ Teacher Characteristics } & Male & 1.86 & 0.67 & \multirow{2}{*}{1.937} & \multirow{2}{*}{0.055} \\
\hline & Female & 1.65 & 0.49 & & \\
\hline \multirow{2}{*}{ Subject Matter Content } & Male & 2.31 & 0.48 & \multirow{2}{*}{1.192} & \multirow{2}{*}{0.236} \\
\hline & Female & 2.21 & 0.45 & & \\
\hline \multirow{2}{*}{ Medium Instruction } & Male & 2.36 & 0.48 & \multirow{2}{*}{0.609} & \multirow{2}{*}{0.544} \\
\hline & Female & 2.30 & 0.50 & & \\
\hline \multirow{2}{*}{ Learning Environment } & Male & 2.35 & 0.65 & \multirow{2}{*}{1.580} & \multirow{2}{*}{0.117} \\
\hline & Female & 2.17 & 0.61 & & \\
\hline \multirow{2}{*}{ Instructional Resources } & Male & 2.58 & 0.48 & \multirow{2}{*}{2.530} & \multirow{2}{*}{$0.013^{*}$} \\
\hline & Female & 2.34 & 0.59 & & \\
\hline \multirow{2}{*}{ Curriculum } & Male & 2.34 & 0.48 & \multirow{2}{*}{0.995} & \multirow{2}{*}{0.322} \\
\hline & Female & 2.25 & 0.51 & & \\
\hline \multirow{2}{*}{ Parental Support } & Male & 2.19 & 0.65 & \multirow{2}{*}{2.199} & \multirow{2}{*}{$0.030 *$} \\
\hline & Female & 1.93 & 0.64 & & \\
\hline
\end{tabular}

Note: Male $=61 ;$ Female $=62 \wedge$ equal variances assumed

*significant at $\mathrm{p}<0.050$

As seen from the table, there is a statistically significant difference between the means of students' challenges in learning science in terms of instructional resources $(\mathrm{t}=2.530, \mathrm{p}<0.05)$. This implies that male students $(\mathrm{M}=2.58$, $\mathrm{SD}=0.48)$ face greater challenges in terms of learning than females $(\mathrm{M}=2.34, \mathrm{SD}=0.59)$ in terms of instructional resources. Further, there is a statistically significant difference in parental support according to sex $(\mathrm{t}=2.199$, $\mathrm{p}<0.05)$. This suggests that male students $(\mathrm{M}=2.19$, $\mathrm{SD}=0.65$ ) face greater challenges in learning than females $(\mathrm{M}=1.93, \mathrm{SD}=0.64)$ in terms of parental support.

Meanwhile, there are no significant differences in learning science challenges according to sex in terms of student motivation, cognitive ability, teacher characteristics, subject matter content, medium of instruction, and curriculum.

\section{Conclusions and Implications}

The study sought to ascertain the different challenges in learning science among Grade 9 students in the junior high school under the $\mathrm{K}$ to 12 curriculum in the Philippines. The study found out that the greatest challenge encountered by junior high school students in learning science is on the instructional resources and medium of instruction, the least is on the teacher characteristics and student motivation. The 9 students do not much encounter challenges in learning science based on the survey results. However, the interview transcripts revealed that the junior high school students encounter a myriad of challenges ranging from curriculum, cognitive ability, instructional resources and learning environment.
There are significant differences in terms of instructional resources and parental support when respondents are grouped according to sex wherein males encounter greater challenges than their female counterparts. Likewise, the proposed action plan (Appendix B) was crafted based on the survey and interview results to further minimize the students' challenges in learning science. The use of varied and innovative pedagogical practices may also be considered by the teachers to better explain complex and complicated topics for better Science learning in a $\mathrm{VUCAD}^{2}$ world.

\section{Appendix A. Challenges in Learning Science Questionnaire (CLSQ)}

\section{Part I. Demographic Profile}

Please affix check mark $(\sqrt{ })$ in the box and fill in the blanks with the required information.

Name (Optional):

$\begin{array}{lllll}\text { Age } & \square 12 & \square 13 & \square 14 \quad \square 15 & \square 16 \\ & \square 17 & \square 18 & \square \text { above } 18 & \\ \text { Sex } & \square \text { Male } & \square \text { Female }\end{array}$

\section{Part II. Challenges in Learning Science}

Using the scale below, check the number that best describes your experiences in learning science.

\section{4- Strongly Agree $\quad 3$-Agree 2-Disagree}

1-Strongly Disagree 


\section{A. Student Motivation}

1. I am less interested in our discussion in science.

2. I do not feel motivated whenever we have laboratory activities.

3. I feel bored while working on our performance tasks in science.

4. I do not enjoy learning science concepts.

5. I have psychological fear in science in terms of manipulating specimen in biology that results in problems in learning.

\section{B. Student Cognitive Ability}

1. I face difficulty in solving problems even when similar examples are given.

2. I do not perform well in science.

3. Science is more difficult for me than for many of my classmates.

4. I do not learn things quickly in science.

5. I have poor conceptual and procedural understanding in science.

\section{Teacher Characteristics}

1. My teacher lacks competence and training in science.

2. My teacher does not use innovative and engaging teaching strategies.

3. My teacher does not teach science well.

4. My teacher does not stir my interest in my science classes.

5. My science teacher does not prepare adequately before going to class.

\section{Subject Matter Content}

1. Properties and structure of matter are complex.

2. The parts and functions of animal and plant cell are difficult to understand.

3. Topics about heredity are unclear for me.

4. Biodiversity and evolution involve complex topics.

5. The symbiotic relationship in the ecosystems is hard to understand.

6. The process of calculating force and motion is complicated.

7. Processes in learning about energy are complex.

8. Concepts in geology are not simplified.

9. Topics in meteorology are confusing.

10. Concepts in astronomy are unclear.

\section{E. Medium of Instruction}

1. It is not easy for me to communicate my thoughts in Science using English language.

2. My learning is negatively affected by the use of English as the medium of instruction
3. I have problems in understanding some scientific terms and processes.

4. My teacher speaks most of the time in English in explaining our science lessons.

5. I face problems in expressing myself in English, I am not often allowed to speak in Filipino.

\section{F. Learning Environment}

1. Our classroom is not conducive for learning science.

2. Our classroom atmosphere does not nurture and inspire my participation in our science class.

3. The misbehavior of my classmates in the classroom affects my learning in science.

4. The large number of students in our class makes it difficult for me to concentrate in learning science.

5. I am afraid in participating in the class because of the strictness of my teacher.

\section{G. Instructional Resources}

1. Our school has inadequate laboratory facilities for our laboratory experiments.

2. Our school lacks laboratory apparatuses and tools.

3. Our school has insufficient learner's materials and other reference materials.

4. My teacher uses limited instructional aids in teaching science which makes science teaching difficult.

5. The school lacks support in the purchase of instructional resources in science.

\section{H. Curriculum}

1. My teacher still adjusts in teaching the K-12 spiral curriculum in science.

2. My science subject has insufficient time allocation.

3. The science curriculum is too complex and complicated.

4. I feel that the competencies in the curriculum guide are inappropriate for my grade level.

5. I feel that science subject does not prepare me for my future career.

\section{Parental Support}

1. My parents/ guardians could not assist me financially and materially.

2. My parents/guardians could not assist me in my science projects.

3. My parents/guardians do not support me morally in my studies.

4. I do not solve science problems at home because nobody guides me.

5. My parents/guardians do not attend our science-related programs and school activities. 


\section{Appendix B. Proposed Action Plan}

\begin{tabular}{|c|c|c|c|c|c|}
\hline $\begin{array}{c}\text { Target Challenge } \\
\text { to Take Action }\end{array}$ & Objective/s & Activities & Persons Involved & Duration & Expected Output \\
\hline $\begin{array}{l}\text { 1.Instructional } \\
\text { Resources }\end{array}$ & $\begin{array}{l}\text { To procure } \\
\text { additional } \\
\text { instructional } \\
\text { resources for the } \\
\text { school. }\end{array}$ & $\begin{array}{l}\text { Fund-raising } \\
\text { activity } \\
\text { Project Collab - } \\
\text { school-industry } \\
\text { partnership to } \\
\text { have laboratory } \\
\text { apparatuses and } \\
\text { tools. }\end{array}$ & $\begin{array}{l}\text { Faculty staff; school } \\
\text { administration; } \\
\text { parents; students; } \\
\text { communities; and } \\
\text { other stakeholders. } \\
\text { (industries) }\end{array}$ & Twice a year & $\begin{array}{l}\text { At least } 2 \text { science } \\
\text { laboratory rooms are } \\
\text { equipped with laboratory } \\
\text { apparatuses and tools. }\end{array}$ \\
\hline $\begin{array}{l}\text { 2. Medium of } \\
\text { Instruction }\end{array}$ & $\begin{array}{l}\text { To promote } \\
\text { code-switching in } \\
\text { the teaching and } \\
\text { learning of } \\
\text { science. }\end{array}$ & $\begin{array}{l}\text { Learning Action } \\
\text { Cell (LAC) } \\
\text { Session on } \\
\text { Code-switching in } \\
\text { Teaching the } \\
\text { Sciences }\end{array}$ & $\begin{array}{l}\text { Faculty staff; school } \\
\text { administration; and } \\
\text { students; language } \\
\text { experts }\end{array}$ & Quarterly & $\begin{array}{l}\text { At least } 80 \% \text { of the } \\
\text { teachers are trained on } \\
\text { code-switching's basic } \\
\text { rudiments in a science } \\
\text { class. }\end{array}$ \\
\hline 3. Curriculum & $\begin{array}{l}\text { To inform the } \\
\text { stakeholders about } \\
\text { the science } \\
\text { education } \\
\text { curriculum which } \\
\text { is anchored on the } \\
\text { spiral progression } \\
\text { approach. }\end{array}$ & $\begin{array}{l}\text { Seminar } \\
\text { orientation to } \\
\text { discuss the spiral } \\
\text { curriculum in } \\
\text { Science. }\end{array}$ & $\begin{array}{l}\text { Faculty staff; school } \\
\text { administration; } \\
\text { parents; students; } \\
\text { community folks; } \\
\text { other stakeholders; } \\
\text { curriculum experts }\end{array}$ & 2 days & $\begin{array}{l}\text { At least } 55 \% \text { of the } \\
\text { stakeholders attended the } \\
\text { curriculum } \\
\text { orientation-seminar. }\end{array}$ \\
\hline 4. Parental Support & $\begin{array}{l}\text { To increase } \\
\text { parental } \\
\text { involvement in the } \\
\text { student's } \\
\text { academic } \\
\text { activities. }\end{array}$ & $\begin{array}{l}\text { Parents and } \\
\text { Teacher } \\
\text { conference } \\
\text { Family Day }\end{array}$ & $\begin{array}{l}\text { Faculty staff; school } \\
\text { administration; } \\
\text { parents; students }\end{array}$ & $\begin{array}{l}\text { Half day in } \\
\text { every end of } \\
\text { the grading } \\
1 \text { day }\end{array}$ & $\begin{array}{l}\text { At least } 90 \% \text { of } \\
\text { parents/guardians attended } \\
\text { the conference and Family } \\
\text { Day. }\end{array}$ \\
\hline
\end{tabular}

\section{REFERENCES}

[1] $\mathrm{K}$ to 12 Science Curriculum Guide. (2016). http://lrmds.deped.gov.ph

[2] Sunga, D. L., \& Hermosisima, M. V. C. (2016). Fostering better learning of science concepts through creative visualization. The Normal Lights, (Special Issue), 50 - 63.

[3] Morales, M.P.E. (2019). Education in a VUCA (volatile, uncertain, complex, ambiguous) world. The Normal Lights, 13(2), v-x.

[4] Manalansan, E.B.R., Fogata, M.A., \& Rogayan, D.V. Jr. (2020). Exploring prospective teachers' reasons for choosing general science as a specialization. Journal of Science Learning, 3(3), 149-155. https://doi.org/10.17509/jsl.v3i3.2 3493

[5] Kaptan, K., \& Timurlenk, O. (2012). Challenges for science education. Procedia - Social and Behavioral Sciences, 51, 763-771. https://doi.org/10.1016/j.sbspro.2012.08.237

[6] Orleans, A. V. (2007). The condition of secondary school physics education in the Philippines: Recent developments and remaining challenges for substantive improvements. The Australian Educational Researcher, 34(1), 33-54. https://doi.org/10.1007/bf03216849

[7] UP-NISMED (2004). In SEI-DOST \& UP-NISMED (2011).
Science framework for Philippine Basic Education. SEI-DOST \& UP NISMED.

[8] Trends in International Mathematics and Science Study (TIMSS). (2008). http://timss.bc.edu.

[9] Jalmasco, N.M. (2014). Science education realities. The Manila Times. https://www.manilatimes.net/2014/05/28/opi nion/columnists/science-education-realities/100096/

[10] Tan, M. C. (2010). Science education in the Philippines: Where to? In current challenges in basic science education. UNESCO.

[11] UNESCO (2010). Current challenges in basic science education. UNESCO Education Sector.

[12] Anderman, E. M., Sinatra, G. M., \& Gray, D. L. (2012). The challenges of teaching and learning about science in the twenty-first century: Exploring the abilities and constraints of adolescent learners. Studies in Science Education, 48(1), 89-117.

[13] Baterna, H. B., Mina, T. D. G., \& Rogayan, D. V. Jr. (2020). Digital literacy of STEM senior high school students: Basis for enhancement program. International Journal of Technology in Education, 3(2), 105-117. https://doi.org/10. 46328/ijte.v3i2.28

[14] Gormally, C., Brickman, P., Hallar, B., \& Armstrong, N. (2009). Effects of inquiry-based learning on students' science literacy skills and confidence. International Journal for the Scholarship of Teaching and Learning, 3(2), 16. https://doi.org/10.20429/ijsotl.2009.030216 
[15] Rafanan, R. J. L., De Guzman, C. Y., \& Rogayan, D. V. Jr. (2020). Pursuing STEM careers: Perspectives of senior high school students. Participatory Educational Research, 7(3), 38-58. https://doi.org/10.17275/per.20.34.7.3

[16] Perera, L. D. H. \& Bomhoff, E. J. \&. Lee, G. H.Y (2014). Parents' attitudes towards science and their children's science achievement. Monash Economics Working Papers. Monash University, Department of Economics, 02-14. https://doi.org/10.1080/09500693.2014.949900

[17] Hassan, A. M. (2016). Functional science and technology education tool for national economic empowerment and development. A Journal of Science, Technology and Mathematics Education, 1(1), 46-51.

[18] Osuolale, O.J. (2014). Problems of teaching and learning science in junior secondary schools in Nasarawa State, Nigeria. Journal of Education and Practice, 5(34).

[19] Zengele, A. G., \& Alemayehu, B. (2016). The status of secondary school science laboratory activities for quality education in case of Wolaita Zone, Southern Ethiopia. Journal of Education and Practice, 7(31), 1-11.

[20] Eyisi, D. (2016). The usefulness of qualitative and quantitative approaches and methods in researching problem-solving ability in science education curriculum. Journal of Education and Practice, 7(15), 91-100.

[21] Kola, J.A. (2013). Importance of science education to national development and problems militating against its development. American Journal of Educational Research, 2013, 1(7), 225-229. https://doi.org/10.12691/education-1-7 -2 .

[22] Erdogan, N. (2016). Communities of practice in online learning environments: A sociocultural perspective of science education. International Journal of Education in Mathematics, Science and Technology, 4(3), 246. https://doi.org/10.18404/ijemst.20679

[23] Buyruk, B., \& Korkmaz, O. (2016). STEM awareness scale: Validity and reliability study. Journal of Turkish Science Education, 13(2), 61-76.

[24] Taber, K. S., \& Akpan, B. (Eds.). (2016). Science education: An international course companion. Springer.

[25] Ambag, R. (2018). Teaching Science in the Philippines: Why and How We can do better. Retrieved at https://www.flipscience.ph

[26] Reusia, D. H. R., Rogayan, D. V. Jr., \& Andres, K. P. (2020). Science education graduates of a state university from 2008-2018: A tracer study. The Normal Lights, 14(1), 56-79.

[27] Quijano, C. (2012). Philippines: The role of language and education in globalization (Published Thesis). University of San Francisco.

[28] Orbe, J., Espinosa, A., \& Datukan, J. (2018). Teaching chemistry in a spiral progression approach: lessons from science teachers in the Philippines. Australian Journal of Teacher Education, 43(4), 17-30. https://doi.org/10.14221/ ajte. $2018 \mathrm{v} 43 \mathrm{n} 4.2$.
[29] Hassan, A. M., Gimba, R. W. \& Chado, M. A. (2016). Effect of Information and Communication Technology (ICT) on gender and achievement of students in basic science and technology at junior secondary school level. Computer Education Research Journal (CERJ), 3(1), 111-126.

[30] Mtsi, N., \& Maphosa, C. (2016). Challenges encountered in the teaching and learning of the natural sciences in rural schools in South Africa. Journal of Social Sciences, 47(1), 58-67. https://doi.org/10.1080/09718923.2016.11893544.

[31] Idiaghe, J.E. (2004). Relationship between educational facilities, teachers' qualifications, school location and academic performance in secondary schools in the Delta State (Doctoral dissertation). Abraka: Delta State University.

[32] Tan, K. C. D., \& Kim, M. (2012). Issues and challenges in science education research. Issues and Challenges in Science Education Research, 1-4. https://doi.org/10.1007/9 78-94-007-3980-2

[33] Moskowitz, G. B. (2005). Social cognition. Oxford Bibliographies Online Datasets. https://doi.org/10.1093/obo /9780199828340-0099.

[34] Lavrakas, P. J. (2008). Encyclopedia of survey research methods. Sage Publications.

[35] Rondaris, M.A.I., Ibañez, A.G., \& Varela, D.V. (2014). Assessment of Alternative Learning System program and performance of graduates in the world of work: Basis for an enhancement mechanism (Published dissertation). Philippine Normal University (PNU), Manila, Philippines.

[36] Schulze, S., \& Lemmer, E. (2017). Family experiences, the motivation for science learning and science achievement of different learner groups. South African Journal of Education, 37(1), 1-9. https://doi.org/10.15700/saje.v37n1a1276

[37] Darling-Hammond, L. (2000). Teacher quality and student achievement. Education Policy Analysis Archives, 8(1). https://doi.org/10.14507/epaa.v8n1.2000

[38] Kwok, S. (2018). Science education in the 21st century. Nature Astronomy, 2, 530-533. https://doi.org/10.1038/s41 550-018-0510-4

[39] Launio, R.M. (2016). Instructional medium and its effect on students' mathematics achievement. International Journal of Multidisciplinary and Current Research, 3, 462-265.

[40] Baker, J., \& Young, B.W. (2014). 20 years later: Deliberate practice and the development of expertise in sport. International Review of Sport \& Exercise Psychology, 7(1), 135-157. https://doi.org/10.1080/1750984X.2014.896024

[41] Dunlosky, J. (2013). Improving students' learning with effective learning techniques: Promising directions from cognitive and educational psychology. Psychological Science in the Public Interest, 14(1), 4-58.

[42] Dunton, J. B., \& Co, W.S. (2019). Spiral progression approach in teaching science and the performance of learners in District I, Capiz. Journal of Physics: Conference Series, 1254, 012045.https://doi.org/10.1088/1742-6596/12 $54 / 1 / 012045$ 